\title{
A Comparative Study of the Administrative Efficiency of Principals in Public and Private Secondary Schools in Maroua, Far North Region, Cameroon
}

\author{
Joseph Besong Besong ${ }^{1}$ \\ ${ }^{1}$ Department of Sciences of Education, Higher Teachers' Training College, University of Maroua, Cameroon \\ Correspondence: Joseph B. Besong, Department of Sciences of Education, Higher Teachers' Training College, \\ University of Maroua, P.O.Box 55, Maroua, Cameroon. Tel: 237-7452-4558. Email: besong.joseph@yahoo.com
}

Received: March 9, 2011

Accepted: March 24, 2011

Online Published: March 14, 2013

doi:10.5539/ijbm.v8n7p90

URL: http://dx.doi.org/10.5539/ijbm.v8n7p90

\begin{abstract}
This study sought to compare the administrative efficiency of principals in public and private secondary schools in Maroua, capital of Far North Region. Two research questions were posed and one null hypothesis formulated to guide the study. Thirty (30) schools principals i.e. 15 from the public and 15 from the private sectors were used for the study. A questionnaire entitled; Comparative Study of Administrative Efficiency in Public and Private Secondary Schools Questionnaire (CSAEPPSSQ) which consisted of 48 items was used to elicit information from the respondents. While mean scores and standard deviations were used to analyze the research questions, $t$-test statistic was used to test the only hypothesis at 0.05 level of significance. The result indicated that the public and private secondary schools principals differed significantly in terms of the level of delegation of functions motivation of staff, general rapport, aesthetics of school premises, management of funds and administration procedures but did not differ in terms of supervision, enforcement of rules and regulations, decision-making, organization of meetings, supply of equipment and protection of school property. From the above, recommendations were made, among which was the appointments of principals in both public and private secondary schools be based on qualifications and experience.
\end{abstract}

Keywords: comparative, administrative, efficiency, public and private

\section{Introduction}

The school is an institution or a human industry established for refining human beings in terms of skills, behaviour and all-round excellence. To achieve these objectives, an efficient personnel or administrator must head such an institution. As regards the secondary schools, whether public or private, the manager is generally regarded as the "principal". A Cameroonian who must head the institution is supposed to have a proven ability and the knowledge to make the institution achieve the stated objectives efficiently.

\section{Literature Review}

Efficiency is doing things rightly, that is, using minimum inputs to achieve maximum outputs. The principals of both public and private secondary schools have to use the limited resources to achieve maximum productivity. Since means are scare, the principals need to be efficient. Efficiency refers to the relationship between the inputs in and the outputs from the system. A system (i.e. school) or an activity is said to be efficient, if it can produce maximum output with a given quantity of input or a given quality of output with the minimum quality of inputs. According to Rogars and Ruchlin (1971), efficiency is closely related to productivity or it is through maximized productivity that maximum efficiency is achieved. The author observed that there were two aspects of maximization of productivity, namely, any given set of inputs should be utilized so as to produce the largest value of output; secondly, for specified output and quality level, inputs should be chosen and utilized so as to minimize production. Sheehan (1973) refers to efficiency as the degree of waste on resources (or its absence) within a given technique. In other words, an organization is efficient if it produces the required benefits and maximizes or avoids wastages in its entirety. Efficiency is the ratio between output of an organization, establishment or department and the inputs used in producing the output (Akangbou, 1987). The principal is efficient if he produces the required benefits in his school and maximizes or avoids wastages in his entirety. In other words, efficiency could be inferred to mean minimization of inputs to achieve a given level of output or 
maximization of output with a given level of inputs.

Efficiency of education is the relationship between the outputs of the principals of both public and private secondary schools. According to Ojedele (1998), efficiency is seen as a situation in which the educational administrator is able to satisfy the needs of the human elements within the system in admission procedure, staffing, management of funds and other variables in the business of education so as to achieve maximum output with little input or effort. Oluchhukwu (1999) refers to efficiency of the school system as the relationship between the inputs (human and material resources and also administrative exigencies or demands) from the school system and outputs (academic achievement or excellence of students, high level of productivity). In this regard, if a school system produces maximum output with minimum possible inputs, the system is said to be efficient.

There are two types of educational efficiency, namely, internal and external efficiency. Internal efficiency of education refers to the relationship between learning achievements (outputs) and corresponding inputs used to create them (Ebhohimen, 1989). Longe and Durosaro (1988) remark that internal efficiency is the extent to which the educational system's (pprincipal's) ability to maximize cost and reduce wastage resulting from repetition, drop-out and administrative incompetence.

Before internal efficiency is measured, the outputs and inputs of the educational system (i.e. principal administrative scale) must be measured. In other words, the ratio of the inputs to the outputs of educational system determines the internal efficiency. For example, an output in a given cycle of education or in a given secondary school is the number of successful students who have completed the cycle influenced by the educational inputs. The educational inputs comprise the buildings, academic and non-academic staff, teaching materials, conducive learning environment, text books and good community relationships. These may be aggregated in terms of expenditures per student-year. Thus, the student's year is the basic unit of measurement of input in education. The cohort is used in measuring the efficiency.

The cohort analysis shows the student's flow pattern through the educational cycle. If it takes 6 years to complete the secondary school level of education under conditions of maximum efficiency, the cohort may include promotion rate, motivation, drop-out and prudent financial management by the principal. The ideal input - output ratio in such a situation in formula 1 .

$$
\frac{\text { Input }}{\text { Output }}=\frac{6}{1}=6
$$

Source: Babalola J. B., \& Ayeni, A. O. (2009). Educational management, theories and tasks.

The illustration is in an ideal situation. However, perfect efficiency is never achieved in any country as a result of wastage in the school system in terms of repetition of classes and drop-out of students from the school. To this end, the actual numbers of successful completers as shown by the cohort analysis are used to determine the actual input - output ratio as shown in formula 2.

$$
\frac{\text { Input }}{\text { Output }}=\frac{\text { Actual Stuent Year }}{\text { Successful Completers }}
$$

Source: Babalola J. B., \& Ayeni, A. O. (2009), Educational Management, Theories and Tasks. p. 52.

For the purpose of determining the degree of inefficiency at this level of education, the actual input - output ratio is related to the ideal input - output ratio to obtain the wastage ratio as shown in formula 3.

$$
\text { Wastage }=\frac{\text { Actual Input }- \text { Output Ratio }}{\text { Ideal Input }- \text { Output Ratio }}
$$

Assuming that the actual - input ratio is 7.5 then wastage ratio will be as shown in formula 4 .

$$
\frac{7.5}{6}=1.25
$$

External efficiency in education refers to the extent which education takes care of the broad, social economic and political goals of the community (akangbou, 1987). Adepoju (2000) defines external efficiency of an educational system as the ability of the systems output to meet the needs and aspiration of the society or particular community. External efficiency of the school system, according to Oluchukwu (2000), is the fit between education and the needs of the society, especially in the labour market. From these definitions, it could be informed that an educational efficiency will be externally efficient if its outputs meet the needs of the society. 
If the system does not, it calls for re-examination of the educational system with a view to making the system more responsive to the yearnings and aspirations of the society. Such measures may include principal's administrative activities of both public and private secondary schools in terms of supervision, delegation of functions, discipline or enforcement of rules and regulations, decision- making, quality control and management of funds, extra (etc).

For education to be a veritable tool for public and private secondary schools meant for national development various measures should be put in place to maintain and improve the prescribed standards. Apart from policy from ministry of education, the Presidential Decree on Education enforces the National Minimum Standard and Establishments of Institutions (NMSEI) has addressed the issue of maintaining minimum standards at different levels of education.

According to Fadipe (2000), efficiency indicators are the parameters which guide the principals to ensure that higher standards are maintained so that both public and private secondary schools run according to the laid down regulations.

Thomas (1971), Yolote (1976), Nwagwu (1983), and Fadipe (2000) have identified a number of quality control measures in education. These measures are indicators or tools for principals' administrative efficiency. Thomas (1971) identified space, equipment, books, materials, teachers or staff and administrative personnel as inputs of principals' efficiency. According to Yoloye (1976) there are six indicators of educational efficiency which principals require: quality of teachers or staff, quality of facilities, quality of instruction, quality of evaluation procedures, quality of motivation or morale and quality of resource or financial management. Nwagwu (2004) also listed four indicators necessary for assessing the quality of output of the secondary schools in the educational system. These included: quality and number of students admitted, quality of the dedication and number of teachers available, quality and quantity of the available infrastructure and quality and number of managerial personnel such as school inspectors and supervisors. Fadipe (2000) on the other hand, mentioned six efficiency indicators for control of quality in secondary schools education in general in Cameroon. These include, teaching resources, financial resources, the teachers or academic staff, the learners (students), text books and infrastructural facilities. Summarily, the degree of quality of the identified indicators determines the degree of the output of the principal's administrative efficiency. The higher the quality of the output, the more efficient the principals' administration all the variables mentioned in this study.

\section{What Are the Obstacles to Efficiency of Principals' Administration?}

There are various factors which militate against principals' administrative efficiency in public and private secondary schools in Cameroon in general and in Maroua Capital of Far North Region in particular. Some of these factors include inadequate funding, shortage of physical structures, shortage of qualified and motivated staff, inadequate instructional materials, curriculum deficiency and lack of effective supervision and monitoring. The study of Ajayi (2006) showed that between 1999 and 2006, the average budgetary allocation to education by the Government of Cameroon was less than $10 \%$. This was evident that education in Cameroon was not adequately funded. The study further showed that Cameroon allocation was far less below the UNESCO recommended allocation of $26 \%$ which countries should budget for education. This is an indication that principals in public and private secondary schools may be inadequately funded in Maroua, Capital of Far North Region. This could therefore be responsible for the poor state of infrastructures.

Physical facilities such as classrooms, libraries, laboratories, workshops, furniture and fittings are required for effective academic work. The MEC (1990/91) survey indicated that approximately 4.9\% of Cameroonian schools had no building. The survey equally showed that there was a shortfall of $62.4 \%$ in pupils' furniture and $62.5 \%$ in teachers' furniture, nation-wide. Adeogun (2001), Akumah and Gana (2005) reported that there were inadequate physical facilities in Cameroonian schools in general and in public secondary schools in Maroua capital of Far North Region in particular. Ajayi (2001) maintained that infrastructures such as laboratories, classrooms, furniture and fittings were still inadequate in public schools in Cameroon generally and in Maroua in particular. The findings showed that even after six years of commencement of Universal Basic Education (UBE) programme, the situation of inadequacy of the aforementioned infrastructures in public schools in particular has made the environment not conducive for teaching and learning.

No educational system can rise above the quality of its teachers. Effective instruction delivery, to a large extent, depends on the availability of qualified and motivated teachers. Igwe (2004) and Obanya (2006) have identified inadequate number of qualified teachers, irregular payment of teachers' salaries and teachers' dissatisfaction with their conditions of service as obstacles to principals' administrative efficiency especially in public secondary schools due to the number of schools managed by government. This may not be so in private 
secondary schools with fewer student population and staff.

The importance of instructional materials in teaching-learning process cannot be over emphasized. In other words, they are important elements for effective teaching and learning and thus promote principals' administrative efficiency if they are adequately supplied. This is in consonance with Ajayi (2006) who remarked pathetically that instructional materials required for effective teaching and learning in some African countries like Cameroon schools were grossly inadequate. Furthermore, a Situation and Policy Analysis (SAPA) study conducted in 1992 for schools showed that $77 \%$ of pupils had no text books at all while $36 \%$ had no writing materials and also many as 3\% of schools had no chalk, while equipment for science, agricultural science, home economics, arts and craft were lacking in majority of schools. In the same vein, Abdulkareem (2002), observed that instructional materials in public schools were grossly inadequate in spite of the immense benefits of such materials to users (output) and in promoting the principals' administrative efficiency.

Curriculum in Cameroon is not responsive enough to the needs and aspirations of the people. Since principals in both public and private secondary schools are not involved in the development or designing of school curriculum. They are bound to accept what so ever is planned and given to schools for implementation. This may hinder principals' administrative efficiency in terms of input - output ratio. In other words, it may affect productivity and thus obstruct principals' zeal because the essence of secondary school education is to produce people who replicate what they are taught theoretically in practical term i.e. produce things for survival of humanity.

Effective supervision and monitoring are quality control measures. Where school are not effectively supervised and monitored, the quality of the school output is at stake. In recent time secondary schools in Cameroon in general and in Maroua Capital of Far North Region in particular, are not regularly supervised and monitored (Adepoju, 2000). As a result, most of the problems facing the school system are not ascertained for urgent solutions. Principals' of public secondary schools may suffer this ineffective supervision and monitoring in view of the fact that there are many secondary schools with a few personnel in the inspectorate cadre of the Ministry of Education at the State and Regional Levels. This may be lack of fund to educate some personnel through in-service training. Funds too, may be lacking in the procurement of means of transport, reporting materials and office accommodations. For private secondary schools, inspection is hardly conducted, hence founders may not be well vested in the importance of inspection and monitoring services (Ogunnu, 2002), and therefore principals' administrative efficiency may be hampered.

\section{Research Questions}

The following research questions were posed for the study:

1) How efficient are the principals of public secondary schools in the administrative of their schools?

2) How efficient are the principals of private secondary schools in the administrative of their schools?

\subsection{Hypothesis}

Ho: There is no significant difference $(\mathrm{p}<.05)$ in the administrative efficiency of the Public and private secondary schools.

\subsection{Significance of the Study}

The study on comparative study of administrative efficiency of principals of public and Private secondary schools are significant in the following ways:

1) It will help the principals of both public and private secondary schools know their strengths and weaknesses in the management of secondary schools in terms of human and material resources.

2) It will help the employers of principals of both public and private secondary schools to employ and retain efficient principals.

3) It will help employers to motivate their principals in terms of regular payment, promotions and in-service training.

4) It will help employers to allow their principals or give free hand in the management of their secondary schools, especially in the private sector.

5) It will enable employers of principals of both public and private secondary schools to consider only experts in educational administration and planning as principals in their secondary schools. 


\section{Methodology}

The study was essentially a survey but used ex - post - facto design approach. This was because the researcher had no direct control of the independent variables hence their manifestations had already occurred or because they were inherently not manipulable. It was consensus hence it covered almost the entire population used in the study (Isangedighi, Joshua, Asim, and Ekuri, 2004). The data were collected from the study population to find out facts about the present phenomena from public and private secondary schools within the study area. Only principals who have served from 5 years and above in both public and private secondary schools were used in the study to obtain a large population and for convenience of data collection Thirty (30) principals in the study were stratified based on the characteristic of years of service used in the study. The instrument used was Comparative Study of Administrative Efficiency in Public and Private secondary schools Questionnaire (CSAEPPSSQ).

\subsection{Validity of the Instrument}

Validity is the extent to which an instrument measures what it is supposed to measure. Simple English expressions of the statements were framed showing their relationship of the construct to the research questions. The questionnaire items were further shown to colleagues and other experts in evaluation. These items were then examined and proved in terms of validity, relevance and appropriateness for the study.

\subsection{Reliability of the Instrument}

In other to establish the reliability of the instrument, a trial test of the instrument was carried out in ten (10) secondary schools in Maroua, Capital of Far North Region comprising twenty (20) principals made of two from each of the ten (10) public and private secondary schools. Principals used in the trial test study were not in the main study. For the questionnaire, split-half reliability method was used in measuring the instrument. The correlation of the odd and even responses was first computed using the Pearson Product Moment correlation coefficient analysis of the items of the variable used in the study. To test the instrument the Spearman Brown Prophecy formula was applied and the result of the reliability indices between 0.78 and 0.91 . The reliability for each of the variable was high and reliable according to Nunnally (1978) who stated that any instrument measuring any variable or early constructs a reliability index of 0.50 and above was correct and reliable for use.

\subsection{Data Collection Procedure}

The researcher obtained permission from principals of both public and private secondary schools respectively within the study area. The principals gave different data and time for the administration of the questionnaire. The instrument was administered to the principals in their schools as scheduled and the completed copies were collected on the spot to avoid attrition.

\subsection{Data Analysis}

The data generated were analyzed using mean scores and standard deviations and independent t-test statistic at 0.05 significance level. The data collected were analyzed item by item as it concerned the principals in the administrative task in their schools and later on, a comparison was carried out.

\section{Limitations of the study}

Since the research was not an experimental one where control of variables is rigorous, it was difficult to control the behavior of the respondents. So the attitude of some of the respondents refusing to adequately complete the questionnaire administered to them posed a constraint. However, all the copies of the questionnaires were retrieved. The large area of the research and topography of the area where some institutions were located made the researcher's several trips to the area very difficult and stressful. But that notwithstanding, the researcher did what he intended to do.

\section{Results}

\subsection{Research Question One}

How efficient are the principals of public secondary schools in the administration of their schools?

The data for answering the above research question are shown in tables 1,2 and 3. 
Table 1. Principals' administrative efficiency in public secondary schools

\begin{tabular}{llccc}
\hline \multicolumn{1}{c}{ Item } & $\mathrm{N}$ & Mean & $(\mathrm{SD})$ & Decision \\
\hline Attendance to Work & 15 & 3.54 & 1.00 & Agree \\
Supervision of Teachers & 15 & 2.80 & 1.70 & Agree \\
Delegation of Functions & 15 & 2.80 & 1.43 & Agree \\
Enforcement of Rules & 15 & 3.75 & 0.10 & Agree \\
and Regulations & 15 & 2.54 & 0.87 & Agree \\
Decision Making & 15 & 3.00 & 1.15 & Agree \\
Organization of Meetings & 15 & 3.10 & 1.23 & Agree \\
Communication Cues & 15 & 3.41 & 1.70 & Agree \\
Motivation of Staff & 15 & 3.35 & 1.82 & Agree \\
Staffing/Staff Requisition & 15 & 2.20 & 1.43 & Agree \\
Supply of Equipment & 15 & 3.50 & 1.30 & Agree \\
Protection of School & 15 & 2.90 & 0.82 & Agree \\
Property & 15 & 2.70 & 1.00 & Agree \\
General Rapport & 15 & 3.55 & 2.30 & Disagree \\
Aesthetics of School & 15 & 2.42 & 1.00 & \\
Premises & & & & \\
Management of Funds & & & & \\
Admission Procedures & & & & \\
\hline
\end{tabular}

Cluster $\mathrm{x}($ mean $)=3.00$

Cluster $\mathrm{SD}=1.11$

Table 2. Principals' administrative efficiency in private secondary schools

\begin{tabular}{|c|c|c|c|c|}
\hline Item & $\mathrm{N}$ & Mean & (SD) & Decision \\
\hline Attendance to Work & 15 & 3.90 & 1.10 & Agree \\
\hline Supervision of Teachers & 15 & 2.65 & 1.16 & Agree \\
\hline Delegation of Functions & 15 & 2.80 & 1.26 & Agree \\
\hline $\begin{array}{l}\text { Enforcement of Rules and } \\
\text { Regulations }\end{array}$ & 15 & 2.10 & 1.06 & Disagree \\
\hline Decision Making & 15 & 2.44 & 1.00 & Agree \\
\hline Organization of Meetings & 15 & 2.50 & 1.30 & Disagree \\
\hline Communication Cues & 15 & 2.00 & 0.45 & Agree \\
\hline Motivation of Staff & 15 & 3.80 & 1.08 & Agree \\
\hline Staffing/Staff Requisition & 15 & 3.00 & 1.15 & Agree \\
\hline Supply of Equipment & 15 & 3.50 & 1.15 & Disagree \\
\hline Protection of School Property & 15 & 2.20 & 1.60 & Agree \\
\hline General Rapport & 15 & 4.80 & 1.11 & Agree \\
\hline Aesthetics of School Premises & 15 & 2.18 & 1.10 & Agree \\
\hline Management of Funds & 15 & 3.00 & 1.20 & Agree \\
\hline Admission Procedures & 15 & 2.00 & 1.15 & Disagree \\
\hline
\end{tabular}

Cluster $\mathrm{x}($ mean $)=2.50$.

Cluster $\mathrm{SD}=1.0$.

Table 3. Independent t-test analysis showing a comparison in the principals' administrative efficiency in public and private secondary schools

\begin{tabular}{lccccc}
\hline \multicolumn{1}{c}{ Item } & Group & $\mathrm{N}$ & Mean & $\mathrm{O}(\mathrm{SD})$ & Tcrit \\
\hline Attendance to Work & public & 30 & 3.54 & 1.00 & -0.93 \\
& private & & 3.80 & 1.08 & 1.07 \\
Supervision of Teachers & public & 30 & 2.80 & 1.15 & -0.65 \\
& private & & 3.00 & 1.43 & 2.86 \\
\hline Delegation of Functions & public & 30 & 2.80 & & \\
\hline
\end{tabular}




\begin{tabular}{|c|c|c|c|c|c|}
\hline & private & & 2.00 & 0.45 & \\
\hline \multirow{2}{*}{$\begin{array}{l}\text { Enforcement of Rules and } \\
\text { Regulations }\end{array}$} & public & 30 & 3.75 & 0.10 & -0.89 \\
\hline & private & & 4.00 & 1.11 & \\
\hline \multirow[t]{2}{*}{ Decision Making } & public & 30 & 2.54 & 0.87 & -1.38 \\
\hline & private & & 2.18 & 1.10 & \\
\hline \multirow[t]{2}{*}{ Organization of Meetings } & public & 30 & 3.00 & 1.15 & 1.17 \\
\hline & private & & 2.65 & 1.16 & \\
\hline Communication Cues & public & 30 & 3.10 & 1.23 & 0.97 \\
\hline \multirow[t]{2}{*}{ Motivation of Staff } & public & 30 & 3.81 & 1.10 & 4.89 \\
\hline & private & & 2.10 & 1.06 & \\
\hline \multirow[t]{2}{*}{ Staffing/Staff Requisition } & public & 30 & 3.35 & 1.82 & 3.00 \\
\hline & private & & 2.50 & 1.30 & \\
\hline \multirow[t]{2}{*}{ Supply of Equipment } & public & 30 & 2.20 & 1.43 & -1.43 \\
\hline & private & & 3.00 & 1.15 & \\
\hline \multirow[t]{2}{*}{ Protection of School Property } & public & 30 & 3.50 & 1.30 & -1.67 \\
\hline & private & & 3.00 & 1.00 & \\
\hline \multirow[t]{2}{*}{ General Rapport } & public & 30 & 2.90 & 0.82 & 2.33 \\
\hline & private & & 2.20 & 1.62 & \\
\hline \multirow[t]{2}{*}{ Aesthetics of School Premises } & public & 30 & 2.00 & 1.00 & 2.50 \\
\hline & private & & 2.70 & 1.15 & \\
\hline \multirow[t]{2}{*}{ Management of Funds } & public & 30 & 3.55 & 2.44 & 3.38 \\
\hline & private & & 2.30 & 1.00 & \\
\hline \multirow[t]{2}{*}{ Admission Procedures } & public & 30 & 2.42 & 1.00 & -5.10 \\
\hline & private & & 3.90 & 1.00 & \\
\hline
\end{tabular}

Note: $\mathrm{P}<0.05 ; \mathrm{df}=23 ;$ critical $\mathrm{t}-$ value $=1.71$.

Data presented showed that the mean score ranged from 2.20 to 3.55. Apart from items 10 and 15 with mean score of 2.20 and 2.42 having standard deviations of 1.43 and 1.00 regarding the supply of equipment and admission procedures where there seemed to be some inefficiency, the principals were efficient in their administrative tasks. The cluster mean of 3.00 with a standard deviation of 1.11 indicated a high level of efficiency for the public secondary school principals in their task performance.

\subsection{Research Questions Two}

How efficient are the principals of private secondary schools?

The data presented in table 2 showed that the mean scores ranged from 2.00 to 4.80 . Items $4,5,7,11,13$ and 15 having mean scores of 2.10, 2.33, 2.00, 2.20, 2.18, and 2.00 with standard deviations of (SD) 1.06, 1.00, 0.45, 1.60, 1.10, and 1.15 indicate some level of inefficiency while items $1,2,3,6,8,9,10$ and 14 and with mean scores of 3.90, 2.65, 2.80, 2.50, 3.80, 3.00, 3.50, 4.80 and 3.00 indicate efficiency of the principals of private secondary schools in their task performance. The cluster mean of 2.50 with a standard deviation (SD) of 1.05 is also indicative of efficiency in administration.

\section{Discussion}

The result of the two research questions indicated that both the principals of public and private secondary schools in Maroua Capital of Far North Region, Cameroon, performed their administrative tasks efficiently at varying degrees as portrayed by the cluster means. For example the public school principals' means was 3.00 with a standard deviation of 1.11 , while the cluster mean for principals of private secondary was 2.50 with a standard of 1.05. Comparatively, this finding showed that principals in public secondary schools performed more efficient in their administrative efficiency. This was in consonance with Rogers and Ruchlin (1971). The result of their study on efficiency revealed that efficiency was closely related to productivity. In other words, it was through maximized input that maximum efficiency was achieved. Principals in public secondary schools administrative functions included applying for requisition, adequate academic staff, instructional materials for teaching and learning to increase productivity or output measured in terms of successful completers. This culture of requisition for academic staff and instructional materials was not often complied with private secondary schools even if the principals demanded, hence the proprietors did not have a pool of teachers and adequate 
instructional materials as government did. However, this study had shown that principals in private secondary schools were leading in the supply of equipment hence education was a business supported by the deregulation policy.

The findings in table 3 had shown that principals in public secondary schools excelled more in their administrative efficiency in delegation of functions $(\mathrm{x}=2.8, \mathrm{sd}=1.43$; decision-making $(\mathrm{x}=2.54$, $\mathrm{sd}=0.87)$; organization of meetings $(\mathrm{x}=3.00, \mathrm{sd}=1.5)$; communication cues $(\mathrm{x}=3.10, \mathrm{sd}=1.22)$; motivation of staff $(\mathrm{x}=$ $3.81, \mathrm{sd}=1.10)$; staffing/staff requisition, $(\mathrm{x}=3.35, \mathrm{sd}=1.82)$, protection of school property $(\mathrm{x}=3.50, \mathrm{sd}=1.30)$ management of funds $(x=3.55 \mathrm{sd}=2.44)$, and in general rapport $(\mathrm{x}=2.90, \mathrm{sd} .=0.82)$. The principals of public secondary schools delegated functions to heads of department (HODs). This was a means of motivation. This was efficiency technique employed to induce productivity from input of academic staff. When the head of department were incorporated in the administration of the school in terms of supervision of punctuality, it motivated others to inculcate esprit de corps. This supported Ojedele (1998) who opined that efficiency was the ability of the administrator (principal) to satisfy the needs of human elements within the system. Besong (2007) saw motivation as fundamental in efficiency hence it did not mean payments of salaries and promotions only but extended to providing in - service training for academic staff to increase their knowledge and allowing staff to participate in decision making and accepting their suggestions. The author observed that this would make them enforce the decisions taken. The findings of this study supported Fadipe (2000) who identified staff participation in decision - making and financial resources management meetings as important factor for principal's efficiency hence it is doing things well through people. This is a truism that two better heads are better than one.

The matrix in Table Three had shown that principals in private secondary schools performed administratively efficient in attendance to work $(\mathrm{x}=3.80$, sd. $=1.08)$; supervision of teachers $(\mathrm{x} 22.03 \mathrm{sd}$. $=1.15)$; enforcement of rules and regulations $(x=4.00$, sd. $=1.11$; supply of equipment $(x=3.00$, sd. $=1.15)$; and admission procedures $(\mathrm{x}=3.90, \mathrm{sd} .=1.00)$. The findings supported deregulation policy in Cameroon. Education had become a business no matter the category of people in the system. Unemployment too must be responsible for people to be coerced or forced to work (McGregor Theory X, 1964), supervision of teachers must be effective. The principal must enforce rule of law in other to sustain his job. Equally, the academic staff must obey the rules and regulation of their schools to retain their jobs.

The results unearthed further that most of the principals in private secondary schools were proprietors. Therefore, they were responsible for admission procedures and where they delegated function, they provided guide lines for the principals to follow. For aesthetics of the school compound, the principals should motivate admission through physical appearance of the school.

Principals' administration in private secondary schools seemed business-oriented. That is, the principals' objective was for employment and financial gains even though the State Ministry of Education oversaw through external supervision.

A critical look at the two systems i.e. public and private secondary schools operation, it was obvious to draw an analogy that there was much concentration in public schools by government agency charged with educational administration than in private sector secondary schools. Furthermore, there seemed to be more trained and educated manpower in public secondary schools. This affected principals' administrative efficiency than in private secondary schools where the principals were usually those retired from service and those requisite qualification. While principals in public schools were the best collected from the lots, those in private secondary schools seemed to be the remnants from the government of employment. From the findings it was worthy of note that principals' administrative efficiency in public secondary schools was more efficient than their private secondary schools counterparts in nine variables or items as shown in the matrix in Table Three, while the principals' administrative efficiency in private schools is only six items as shown in Table Three.

It has been found that principals in public secondary schools in Maroua performed efficiently in terms of management of funds since they were chief executive of their schools responsible for managing human and material resources. As government budgetary allocation of the state could not meet the expected $26 \%$ approved be UNESCO, principals had to be prudent in their expenditure. This would increase their school income to avert any shortfall in case of subvention for their salaries and other overhead expenditures.

However, this was different in private secondary schools. Sometime the proprietor was the chief executive officer who collected and disbursed funds. In the case of delegation of functions, the principal was not given some power. This made the principal inefficient in terms of financial management. 


\subsection{Recommendations}

From the findings of this work, the following recommendations are:

> Government policy on establishing and managing secondary schools should be state-wide. That is, all secondary schools must abide by the rules and regulations in terms of admission procedures, school fee charged management of human and material resources for input-output ratio. This will lead to principals' administrative efficiency in both public and private secondary schools. In other words, there will be no disparity in terms of input-output for completers hence they will be assets of the state on completion.

$>$ Government agencies of education in charge of inspecting and monitoring should be authorized by law to extend their functions to private secondary schools. Their rapports or observations will facilitate principals' administrative efficiency in the schools in terms of communication with the staff, general rapport and organizing regular meetings in which staff inputs may be reviewed for administrative efficiency.

> Government should emphasize minimum qualification(s) for principals in both public and private secondary schools. This will limit the phobia of employment and salaries of principals. This usually demoralizes some principals' administrative efficiency in terms of initiating new ideas or innovations in their schools.

> Government deregulation idea on establishment and managing schools should encourage those concerned to employ competent principals. These young veteran principals will promote input so as to achieve an excellent output in areas of aesthetics and successful completers, thus, influencing administrative efficiency.

\section{Conclusions}

From the recommendations made from this study, it is concluded that:

$>$ There is disparity in the administrative efficiency of principals in public and private secondary schools in Maroua.

$>$ The administrative efficiency of principals in public secondary schools are in the areas of delegation of functions, decision-making, organization of meetings, communication cues, motivation of staff/requisition, protection of school property, management of funds, and general rapport while those of the principals in private secondary schools were in attendance to work; supervision of teachers; enforcement of rules and regulations; and admission procedures.

> Government intention to make education an instrument of development, "par excellence" is a welcome development but it should encourage the Non-government Organizations (NGOs) and public-spirited individuals who have taken education as business to follow the rules and regulations of establishment and managing schools. This will influence their principals' administrative efficiency.

$>$ Proprietors of private secondary schools should encourage their principals to be re-trained so as to update their knowledge.

$>$ Government supervisory and monitoring Agencies should encourage principals of private secondary schools in terms of communication, regular staff meetings so as to facilitate interpersonal relationship which makes for administrative efficiency. It is said that two heads are better than one.

$>$ Government should influence all those in educational affairs to employ qualified teachers since input-output is a function of the principal's ability.

\section{References}

Abdulkareem, A. Y. (2002). Adequate Provision and Maintenance of Instructional Materials and Textbooks for a successful Implementation of Universal Basic Education Progremme. In TaiwoAjayi, J. O., Fadipe, P. K., Ojedele, \& Oluchukwu, E. E. (Eds.), Planning and Administration of Universal Basic Education (UBE) in Nigeria. Iyebu - Ode: NIEPA Publication.

Adepoju, T. L. (2000). Improving Education Efficiency in Nigeria: A Planner's View. In Fadipe, J. O., \& Oluchukwu, E. E. (Eds.), Educational Planning and Administration in Nigeria in the 21 Century. Ibadan: NIEPA Publication.

Adeogun, A. A. (2001). An Evaluation of Resources Provision and Utilization in Lagos State Public Secondary schools. JOASEM, 1(91), 113-122.

Akangbou, S. D. (1987). The Economics of Education: An introduction. Ibadan, Shaneson C. I. Ltd. 
Akumah, E., \& Gana, D. R. (2005). Deregulating The Provision and Management of Education in Nigeria. In Akpa, G. O., Udoh, S. U., \& Fagbamiye, E. O. (Eds.), Deregulating the Provision and Management of Education in Nigeria. Jos: NAEAP.

Ajayi, I. A. (2006). Achieving Universal Basic Education (UBE) in Nigeria: Strategies for Inproved Funding and Cost Effectiveness. Paper Presented at African Conference on Primary/Basic Education held at University of Botswana, Gaborone.

Ajayi, I. A., \& Ayodele, J. B. (2001). Introduction to Educational Planning, Administration and Supervision. Oshodi, Logos: Yemi Prints.

Babalola, J. B., \& Ayeni, A. O. (2009). Educational Management: Theories and tasks. Lagos: Macmillan Nigeria Publishers.

Besong, J. B. (2007). Heads of Department, Personal characteristic, Organizational Climate and Academic Staff Job Satisfaction in Tertiary Institutions in cross River and AkwaIbom States. Unpublished Ph. D thesis, University of Calabar, acalabar.

Ebhohimen, P. (1989). The Relative Efficiency of Two Class Cohorts: The Case of Bendel State Secondary School during 1979-1985 Period. Journal of Nigerian Educational Research Association, 9, 1-14.

Fadipe, J. O. (2000). Efficiency Indicators for Quality Control in Nigerian School System. In Fadipe, J. O., \& Ojedele, P. K. (Eds.), Management of Nigerian Education: Personnel Administration and Quality in Education. Ibadan: NIEPA Publication.

Isangedighi, A. J., Joshua, M. T., Asim, A. E., \& Ekuri, E. E. (2004). Fundamentals of Research and Statistics in Education and Social Sciences. Calabar: University of Calabar Press.

Longe, R. S., \& Durosaro, D. O. (1988). Analysis of International Efficiency of Secondary Education in Nigeria: A Case Study of Bendel State. AJEM, 2(2), 107-114.

McGregor, D. (1964). The Human Side of Enterprise. New York: MeGraw-Hill.

Nunnally, J. C. (1978). Psychometric Theory (3 rd.). New York: McGraw-Hill.

Nwagwu, N. A. (2004). The Organization and Management of Primary and Secondary Education inNigeria. In Fagbamiye, E. O., Babalola, J. B., Fabunmi, M., \& Ayeni, A. O. (Eds.), Management of Primary and Secondary Education in Nigeria. Ibadan: NAEAP.

Obanya, P. (2006). Teaching Without Teacher, 24 Distinguished Lecture Series. Otto/Ijanikin: Adeniran Ogunsanya College of Education.

Ogunnu, M. A. (2002). The Role of School Inspectors in the Implementation of the Universal Basic Education Scheme in Nigeria. In Ajayi, T., Fadipe, J. O., Ojedele, P. K., \& Oluchukwu, E. E. (Eds.), Planning and Administration of Universal Basic Education (UBE) in Nigeria. Ijebu Ode: NIEPA.

Ojedele, P. K. (1998). Maintaining School Plant for Education: Project Monitoring and School Plant Maintenance. Ibadan: NIEPA.

Oluchukwu, E. E. (1999). School Mapping and Planning for Efficiency in the School System. Paper Presented at the National Workshop on Planning for Quality Education in Nigeria organized by NIEPA. Ondo.

Rogers, D. C., \& Ruchiln, H. S. (1971). Economics and Education: Principles and Applications. New York: The Free Press.

Sheehan, J. (1973). The Economics of Education. London: George Allenn and Unwin Ltd.

Thomas, J. A. (1971). The Productive School. A System Analysis Approach in Educational Administration. New York: John Wiley and Sons Inc.

Yoloye, E. A. (1976). Secondary Education Today and Tomorrow: The Nigerian Principal. Journal of Ancopss, $10-15$. 